\title{
HUBUNGAN STATUS SOSIAL EKONOMI DAN SUBJECTIVE WELL BEING PADA IBU DARI PENYANDANG SKIZOFRENIA
}

\author{
Farida \\ Fakultas Pendidikan Psikologi, Universitas Negeri Malang \\ faridainka55@yahoo.com \\ Nur Eva \\ Fakultas Pendidikan Psikologi, Universitas Negeri Malang \\ Diantini Ida Viatrie \\ Fakultas Pendidikan Psikologi, Universitas Negeri Malang
}

\begin{abstract}
Abstrak
Tujuan penelitian ini adalah untuk melihat ada tidaknya hubungan status sosial ekonomi dengan subjective well being pada Ibu dari penyandang skizofrenia. Status sosial ekonomi adalah kedudukan atau tempat seseorang dalam masyarakat yang dilihat dari tingkat pendidikan, tingkat pendapatan, dan jenis pekerjaan. Sedangkan subjective well being adalah evaluasi individu mengenai kualitas hidupnya. Penelitian ini menggunakan rancangan penelitian kuantitatif deskriptif dengan model korelasional. Populasi dalam penelitian ini adalah para Ibu yang memiliki anak penyandang skizofrenia yang dirawat di Poli Kesehatan Jiwa RSJ. Dr. Radjiman Wediodiningra, Lawang. Teknik pengambilan sampel mengunakan purposive sampling. Ada dua instrumen yang digunakan, yakni kuesioner status sosial ekonomi dan skala subjective well being. Analisis data mengunakan deskriptif dan analisis korelasional. Berdasarkan hasil analisis deskriptif didapatkan kesimpulan bahwa 24 subjek memiliki status sosial ekonomi rendah, dan 22 subjek memiliki subjective well being yang rendah. Selain itu terdapat 16 subjek yang memiliki status sosial ekonomi yang tinggi dan 18 subjek memiliki subjective well being tinggi. Ini berarti status sosial ekonomi dan subjective well being yang dimiliki oleh Ibu dari penyandang skizofrenia sebagian besar rendah. Hasil analisis korelasional menunjukkan nilai korelasi sebesar 0,314. Jadi ada hubungan positif antara status sosial ekonomi dengan subjective well being pada Ibu dari penyandang skizofrenia.
\end{abstract}

Kata kunci: Status Sosial Ekonomi, Subjective Well Being, Skizofrenia.

\begin{abstract}
This research was held to find If there was any relation between financial and social status and subjective well being among mothers of schizophrenic adults children. Financial and social statuses are usually indicated through the level of education, income and work. And one's subjective well being is usually defined as one's subjective evaluation about his or her life quality. This research employed descriptive and correlation methods. The population is mothers of schizophrenic adult children who were being taken care in the hospital in Lawang, East Java. The sampling technique was purposive sampling and there were 2 scales used for data collection. The data was then analyzed and the results showed the correlation value as much as 0,314 . There were only 18 respondents who value their life qualified.
\end{abstract}

Keywords: financial and social status, Subjective Well Being, schizophrenia.

Kebahagiaan di dalam hidup adalah harapan di dalam kehidupan banyak orang. Menurut Seligman (2005) istilah kebahagiaan banyak dikenal dalam psikologi positif. Teori psikologi menggunakan istilah yang lebih tepat yang dapat didefinisikan secara operasional, yakni Subjective Well-Being yang selanjutnya akan disebut dengan SWB. SWB merupakan suatu bentuk evaluasi mengenai kehidupan individu yang bersangkutan. Bentuk evaluasi ini dapat dilakukan melalui dua cara yaitu penilaian secara kognitif, seperti kepuasan hidup dan respon emosional terhadap kejadian, seperti merasakan emosi yang positif.
SWB berbeda dari psychological well-being. Istilah yang terakhir ini merujuk pada sifat eudamonik yaitu bahwa seseorang dikatakan sejahtera psikologis bila mengisi hidup dengan hal bermakna, bertujuan, berguna bagi kesejahteraan orang lain dan pertumbuhan atau kedewasaan dirinya sendiri. Pada sisi lain, SWB karena disebut subjektif, maka seseorang akan menilai sejauh mana dirinya bahagia, tidak stress dan tidak cemas. Pengukurannya jadi lebih subjektif.

Selain itu, SWB juga sifatnya lebih hedonic, mengandung prinsip kesenangan, yaitu sejauh mana orang merasa hidupnya menyenangkan, bebas stress, bebas kecemasan, tidak menyedihkan. Pada intinya, 
SWB adalah perasaan menyenangkan dan terlepas dari rasa-rasa yang tidak menyenangkan. Oleh karena itulah biasanya SWB kemudian dianggap sebagai ekspresi subjektif tentang kebahagiaan.

SWB dipengaruhi oleh beberapa faktor dan salah satunya adalah faktor ekonomi. Sosial ekonomi menurut Abdulsyani (2007) adalah kedudukan atau posisi seseorang yang ditentukan oleh jenis aktifitas ekonomi, pendapatan, dan pekerjaan. Menurut beberapa penelitian, tingkat ekonomi keluarga juga merupakan salah satu faktor yang menentukan keharmonisan keluarga. Jorgensen (dalam Murni, 2004) menemukan dalam penelitiannya bahwa semakin tinggi sumber ekonomi keluarga akan mendukung tingginya stabilitas dan kebahagiaan keluarga. Penelitian yang dilakukan Gloria (2015) menyatakan bahwa terdapat hubungan yang kecil antara kebahagiaan dengan status sosial ekonomi.

Subjective well-being atau kebahagiaan (happiness) sudah sejak lama dianggap sebagai komponen inti dari hidup yang baik (good of life) (Diener, 2000). Individu dengan level subjective well-being yang tinggi, pada umumnya memiliki sejumlah kualitas yang mengagumkan. Individu ini akan lebih mampu mengontrol emosinya dan menghadapi berbagai peristiwa dalam hidup dengan lebih baik. Sedangkan individu dengan subjective well-being yang rendah, memandang rendah hidupnya dan menganggap peristiwa yang terjadi sebagai hal yang tidak menyenangkan dan oleh sebab itu timbul emosi yang tidak menyenangkan seperti kecemasan, depresi dan kemarahan (Diener, 2000). Berdasarkan penjelasan diatas, tidak semua individu memiliki level subjective well-being yang tinggi, sebagaimana hasil penelitian yang dilakukan Pasili dan Canning (dalam Arnett, 2010) menemukan fakta bahwa terdapat kecenderungan rendahnya tingkat kepuasan hidup pada orang tua, karena anaknya mengalami gangguan jiwa skizofrenia.

Skizofrenia adalah gangguan mental kronik, pervasif dan bersifat kambuhan yang umumnya menyerang mereka yang dalam usia produktif dan merupakan penyebab utama disabilitas kelompok usia 15-44 tahun. Dampak dari skizofrenia bagi individu yang terkena, keluarga, dan masyarakat pada umumnya sangat besar. Beban keluarga di antaranya hilangnya produktivitas keluarga, gangguan ritme aktivitas keluarga, stigma yang dibebankan masyarakat pada keluarga dan pasien. Stigma ini kadangkala menimbulkan reaksi emosional keluarga yang merawat pasien skizofrenia yang dapat memperburuk komunikasi antar anggota keluarga yang pada akhirnya meningkatkan ekspresi emosi keluarga pasien. Sebuah penelitian yang dilakukan di Malaysia tahun 2010, menyatakan bahwa $80 \%$ dari caregiver yang menyediakan perawatan rutin merasa terbeban hubungannya dengan keluarga, 71\% melaporkan sering terjadi ketegangan komunikasi di antara anggota keluarga (Phillips et al., dalam Makmuroch, 2014)

Wawancara yang dilakukan oleh peneliti kepada Dokter Poli Jiwa RST dr. Soepraoen - Malang, yaitu bapak dr.Peony, mendapatkan hasil bahwa $60 \%$ pendamping pasien skizoprenia adalah Ibu pasien, sebagian lainnya adalah keluarga pasien seperti ayah, saudara, bahkan ada tetangga yang juga mendampingi dikarenakan pasien tidak memiliki keluarga.

Kemampuan Ibu dalam merawat pasien dengan skizofrenia membutuhkan pengetahuan. Kurangnya pengetahuan keluarga tentang skizofrenia membuat penafsiran dan pemahaman yang salah dalam merawat pasien. Kurangnya pengetahuan keluarga akan mempengaruhi tindakan yang akan dilakukan misalnya dipasung, dikerangkeng dan direndam dalam air kolam. Hal ini tidak hanya terjadi pada keluarga dengan status ekonomi rendah, pendidikan rendah saja namun dialami pula oleh keluarga dengan kalangan atas (Hawari, 2007).

Memiliki anak penderita skizofrenia diakui merupakan tantangan tersendiri bagi Ibu. Tidak sedikit yang mengeluhkan bahwa merawat dan mengasuh anak penderita skizofrenia membutuhkan tenaga dan perhatian yang ekstra karena tidak semudah saat melakukannya pada orang normal. Namun demikian, hal ini harus dapat disikapi secara positif, agar selanjutnya orangtua khususnya Ibu dapat menemukan langkah-langkah yang tepat untuk mengoptimalkan perkembangan dan berbagai potensi yang masih dimiliki oleh putra atau putri mereka yang menderita gangguan skizofrenia (Hendriani,2011).

Besarnya peran Ibu sebagai caregiver, mendorong peneliti untuk mengetahui hubungan antara status sosial ekonomi dan subjective wel-being pada Ibu dari penyandang skizofrenia.

\section{METODE}

Penelitian ini menggunakan metode penelitian kuantitatif dengan variable bebas yaitu status social ekonomi dan variable terikat yaitu subjective well being. Data dikumpulkan melalui skala status social ekonomi dan SWB yang disusun peneliti sendiri. Kedua skala ini melalui proses ujicoba untuk mendapat nilai validitas dan reliabilitasnya.

Populasi dalam penelitian ini adalah ibu dari penyandang skizofrenia yang dirawat di Rumah Sakit 
Jiwa Dr. Radjiman Wediodiningrat. Jumlah populasi dalam penelitian ini tidak terhingga tetapi berdasarkan observasi yang dilakukan peneliti selama melakukan penelitian di Rumah Sakit Jiwa Dr. Radjiman Wediodiningrat tersebut diketahui terdapat kurang lebih 250 pasien skizofrenia semua jenis yang tercatat sebagai pasien rawat jalan. Sampel penelitian ini menggunakan teknik purposive sampling dengan pertimbangan tertentu yaitu:

1. Ibu yang memiliki anak penderita skizofrenia berjenis kelamin laki laki atau perempuan

2. Ibu yang memiliki anak penyandang skizofrenia yang tercatat sebagai pasien skizofrenia rawat jalan di Poli Kesehatan Jiwa (PKJ) RSJ Dr. Radjiman Wediodiningrat.

3. Bersikap kooperatif.

4. Mampu berkomunikasi

Berdasarkan ketentuan seperti di atas, maka akhirnya diperoleh 40 responden yaitu para ibu dari penyandang gangguan skizophrenia.

\section{HASIL DAN PEMBAHASAN}

Hasil penelitian ini menunjukkan bahwa $40 \%$ dari sampel penelitian memiliki status sosial ekonomi tinggi dan $60 \%$ sampel memiliki status sosial ekonomi rendah. Jadi dapat disimpulkan bahwa sebagian besar subjek berada dalam klasifikasi status sosial ekonomi rendah. Sedangkan sebanyak 22 responden dari 40 responden menilai bahwa SWB yang dimiliki termasuk rendah. Hal ini dapat dipahami mengingat bahwa responden yang terlibat dalam penelitian ini adalah para ibu yang mayoritas tidak bekerja secara formal dan lebih banyak menghabiskan waktunya menjadi ibu rumah tangga yang juga harus mengurus anaknya yang menjadi penyandang skizoprenia.

Selain itu membantu orang dengan gangguan mental bukanlah situasi yang sangat mudah. Seringkali menimbulkan frustasi, karena pada saat-saat tertentu bahkan komunikasi dengan penderita tidak dapat berlangsung dengan baik. Belum lagi stigma terhadap gangguan mental tersebut seringkali merupakan hambatan besar. Keluarga yang memiliki anggota dengan gangguan kerap kali mengalami berbagai emosi seperti rasa takut, rasa bersalah, rasa marah, frustasi, rasa malu, dan perasaan tidak berguna. Stigma terhadap penderita juga kerap membuat keluarga menyembunyikan anggota keluarga tersebut, atau bahkan mengasingkan mereka (Makmuroch, 2014). Sehingga sesungguhnya dapat diduga bahwa para Ibu yang mengurus anaknya yang menyandang gangguan skizophrenia akan memiliki SWB yang rendah.
Selanjutnya uji hipotesis dilakukan untuk melihat ada atau tidaknya hubungan antara status sosial ekonomi dengan subjective well being. Dengan menggunakan teknik uji korelasi product moment pearson diperoleh hasil korelasi sebesar $\mathrm{r}=0,314$. Hal ini menunjukkan adanya korelasi antara status sosial ekonomi dan subjective well being (SWB). Seperti dikemukakan, SWB adalah penilaian orang tentang kualitas hidupnya dan kualitas hidup ini adalah produk dari interaksi antara sejumlah factor psikologis terkait kesehatan, social, lingkungan dan ekonomi. Sehingga ekonomi menjadi bagian yang tak dapat dipisahkan dari masalah SWB ini.

Sebagaimana diungkapkan oleh Diener (2000) bahwa kepuasan hidup itu merupakan evaluasi kognitif atas kehidupan seseorang dan penilaian tentang SWB tidak dapat dipisahkan dari penilaian orang akan kondisi social ekonominya. Dimana-mana biaya diperlukan untuk mendapatkan kepuasan meskipun kepuasan tidak harus diperoleh dengan mengeluarkan biaya.

\section{DAFTAR RUJUKAN}

Abdulsyani. 2007. Sosiologi, Sistematika, Teori Dan Terapan. Jakarta: PT Bumi Aksara.

Arnett,J.J. 2010. Adolescent storm and stress: reconsidered. American Psychology. 54 (5).317-326.

Diener, E, .2000. "Subjective well-being: The science of happiness and a proposal for national index”, American Psychology, 55 (1), 34-43. PsycARTICLES

Hawari.D. 2007. Pendekatan Holistik Pada Gangguan Jiwa, Skizofrenia. Jakarta.

Hendriani, Wiwin. 2011. Penerimaan Keluarga Terhadap Individu Yang Mengalami Keterbelakangan Mental, www.Republika.co.id (10 Agustus 2011).

Irmansyah. 2005. Faktor genetika skizofrenia. http.://www. Schizophrenia.

Makmuroch, 2014. Keefektifan Pelatihan Ketrampilan Regulasi Emosi Terhadap Penurunan Tingkat Ekspresi Emosi Pada Caregiver Pasien Skizofrenia di RSJ. Daerah Surakarta. Wacana: Jurnal Psikologi vol.6 no.11 Januari 2014

Seligman, Martin EP. 2005. Authentic Happiness. Bandung: Mizan Media Utama.

Sugiyono. 2011. Metode Penelitian Kuantitatif, Kualitatif dan R\&D.Bandung: Afabeta 